\title{
5. QUALITY ASPECTS OF PRODUCT DESIGN IN ARTISTIC EDUCATION
}

\author{
Bard Bajçinovci, Uliks Bajçinovci, \\ Elena Rexha, Bujar Bajçinovci ${ }^{235}$
}

\begin{abstract}
The University of Prishtina "Hasan Prishtina" is the biggest higher education institution in Kosovo, which ever since its foundation has held the main burden of education and the development of the Kosovar society. If in the past the University of Prishtina was not only a hearth of knowledge, but also an icon of Kosova's high education, now its mission is to offer stable and qualitative education to the new generation, functioning as an asset for the development and the strengthening of the Kosovar society. Currently, the UP is the biggest higher education institution in the Kosovo, with 42.006 students, above 1.000 academic staff members and around 350 administrative staff members, accommodated in 14 Academic Units. The research conducted in this paper reflects quality aspects in artistic education for sustainable product design, especially in art, architecture, creativity and innovation in academia curricula. The research methods consist of empirical observation in academia, direct observation of teaching methods, and promoting contemporary interactive teaching methods. To perceive a clearer research data, exploring was made within: The department of Architecture, Department of Anthropology-Archeology, The faculty of Arts in the University of Prishtina, also with UBT - Higher Education Institution in Kosovo, in the context of the possibilities for the improvement of the curricula's, within actual and accredited academic frameworks. Research concludes that new teaching strategies must involve a new closeness, a brand new and more refining holistic system, as a response to less functional academic curriculums.
\end{abstract}

Key words: Artistic Education, Quality Aspects, Product Design, Academia

\section{Introduction}

The University of Prishtina "Hasan Prishtina" is the biggest higher education institution in Kosovo, which ever since its foundation has held the main burden of education and the development of the Kosovar society. If in the past the University of Prishtina was not only a hearth of knowledge, but also an icon of Kosova's high education, now its mission is to offer stable and qualitative education to the new generation, functioning as an asset for the development and the strengthening of the Kosovar society. Currently, the UP is the biggest higher education institution in the Kosovo, with 42.006 students, above 1.000 academic staff members and around 350 administrative staff members, accommodated in 14 Academic Units. ${ }^{236}$ "The Faculty of Arts at the university of Prishtina are founded from the Academy of Art, which was established by the Assembly of Kosovo in 1973. The Academy started working on of the academic year 1973/74, and in the timeline of development in the academic year 1986/87, the Academy was transformed into the Faculty of Arts, with the title Faculty of Arts in Prishtina. In this context, the establishment of the Academy and later of the Faculty of Arts

\footnotetext{
235 Student, cand.MSc., email: bb34218@ubt-uni.net, Student, cand.MSc., UBT. Architecture - Spatial Planning from Prishtina, email: ub35398@ubt-uni.net, Student, cand.BSc., email: elenarexha3@gmail.com, Associate Professor PhD., University from Prishtina, Republic of Kosovo, email: bujar.bajcinovci@uni-pr.edu ${ }^{236}$ University of Prishtina, The Rector's speech. UP -Yearbook 2019.
} 
was the coronation of the many years of efforts of the pioneers of figurative, musical, and dramatic arts. Currently, the Faculty of Arts has three Departments: Department of Figurative Arts, Department of Music, Department of Dramatic Arts. So far, at the Faculty of Arts have graduated more than 900 students in Albanian language. ${ }^{237}$ Product Design, discusses and studies the conceptual phase of the product development process. The main role of the quality aspects is to study, research and learn the process of conceptual product design development, theoretically and practically, singling out the process of creative thinking as a fundamental element in new product development. The product type typology is evolutive and each year diversely, according to current trends in collaboration with wide global trends. The aim of the quality aspects development is to initiate fundamental theoretical and practical principles in the field of product design, including the symbiotic interrelationship of technology advancement, lifestyle, understanding of the role of users, target groups and market segments in the design of products. The main objectives of the system are the subject of various interdisciplinary approaches to study and understand the interrelationship between user research, standards, use, operation and product handling. ${ }^{238}$ In this context the question of, what should be exactly the role of quality aspects in product design and artistic education. Hence, for the future apperception of higher education, it is central to present and carry out an unconventional study or a contemporary way of transmitting knowledge. Hence, "we argue that new contemporary academia challenges should encourage a brand-new complementary study, using and developing new action research theories. strengthened with actions towards the exploitation of all resources, especially in nurturing cognitive development, in order to provide a better learning process. ${ }^{237}$

\section{Materials and Methods}

The research conducted in this paper reflects quality aspects in artistic education for sustainable product design, especially in art, architecture, creativity and innovation in academia curricula. The research methods consist of empirical observation in academia, direct observation of teaching methods, and promoting contemporary interactive teaching methods. To perceive a clearer research data, exploring was made within: The department of Architecture, Department of Anthropology-Archeology, The faculty of Arts in the University of Prishtina, also with UBT - Renowned Higher Education Institution in Kosovo, in the context of the possibilities for the improvement of the curricula's, within actual and accredited academic frameworks. Quality aspects of product design in artistic education and architectural studies was explored through review of timeline of academic workshops, curricula's, and within studio researches of the students in

\footnotetext{
${ }^{237}$ Bajçinovci, B., Bajçinovci, U., Bajçinovci, B. (2019). Interactive Academic Education and its Impact on Urban Development - History and Contemporaneousness. Review of Artistic Education.Vol 18, Is.1.Sciendo. Romania ${ }^{238}$ Bajçinovci, B. (2019). Syllabus of Product Design, The Faculty of Arts. The University of Prishtina.
} 
Master programs of the department of architecture in the University of Prishtina, and UBT. With this paper the objective was to present an evolutive teaching methods in academia. Furthermore, describing the teaching methods with the emphasis on creativity in education, which directly reproduce actions on artistic product design.

Tab. no. 1. University of Pristina by numbers. (UP -Yearbook 2019; Bajçinovci, 2019)

\begin{tabular}{l|l|l|l} 
Academic Unit & $\begin{array}{l}\text { Academic } \\
\text { Staff }\end{array}$ & $\begin{array}{l}\text { Administrative } \\
\text { Staff }\end{array}$ & $\begin{array}{l}\text { Current } \\
\text { Students }\end{array}$ \\
\hline Faculty of Philosophy & 58 & 18 & 3059 \\
\hline Faculty of Mathematics and Natural Sciences & 105 & 28 & 2841 \\
\hline Faculty of Philology & 101 & 14 & 2541 \\
\hline Faculty of Law & 56 & 20 & 6024 \\
\hline Faculty of Economics & 63 & 20 & 8095 \\
\hline Faculty of Civil Eng. and Architecture & 89 & 11 & 2329 \\
\hline Faculty of Electrical and Computer Eng. & 37 & 13 & 1801 \\
\hline Faculty of Mechanical Engineering & 40 & 11 & 1281 \\
\hline Faculty of Medicine & 252 & 25 & 3322 \\
\hline Faculty of Arts & 161 & 12 & 828 \\
\hline Faculty of Agriculture and Veterinary & 45 & 19 & 1652 \\
\hline Faculty of Physical Education and Sports & 23 & 8 & 832 \\
\hline Faculty of Education & 57 & 12 & 3380 \\
\hline Central Administration & & 301 & \\
\hline Total & 1087 & 512 & 37985
\end{tabular}

On the other side, "the industry system in the 20th Century have undergone cardinal transformations as a result of the development of science, technology, the growth of the economic base of society and the growth of the human living standards. Historically, Kosovo's industry has gone through various stages of its development and fully dependent on the economic system. In general, Kosovo's industrial development was based on the exploitation of raw materials and their processing to a certain degree, but not to a satisfactory degree of processing and finalization." ${ }^{239}$ Furthermore, according to the result presented in Table 2, there is a lack of variety of courses in organization of the study programs, therefore we need a substantial rethinking of what we have to offer as an attractive curriculum. Hence, the current resolution of the academic situation, formally accomplish legal academia standards cannot solve the actual and future challenges. Challenges, that are associated with the globalization, development of technology, life style, and global world trends surely needs a much more holistic approach.

\footnotetext{
${ }^{239}$ Bajcinovci, B., Aliu. V. (2018). Visual Organization of Industrial Functional Compositions, JOSHA. Freiburg. Germany.
} 
Tab. no. 2. Students satisfaction with current study programs. (Eurostudent.eu/113, 2016; Bajçinovci, 2018)

\begin{tabular}{|c|c|c|c|c|}
\hline & $\begin{array}{l}\text { (Very) } \\
\text { Well }\end{array}$ & Fairly satisfied & (Some) Dissatisfied & Total \\
\hline & percent & percent & percent & percent \\
\hline 1. Quality of teaching & 48.9 & 33.5 & 17.6 & 100 \\
\hline $\begin{array}{l}\text { 2. Organization of } \\
\text { studies }\end{array}$ & 41.6 & 31.4 & 27 & 100 \\
\hline 3. Variety of courses & 26 & 23 & 51 & 100 \\
\hline 4. Study facilities & 38.6 & 23 & 38.4 & 100 \\
\hline
\end{tabular}

\section{Discussions}

The holistic process in artistic education is associated within permanent activities thru all phases of studying. Especially in the product design, where teaching has the character of interactive discussions, engaging in discussion all students, academia and community participants. Also, courses aim to encourage working in groups, within concrete researches in the form of design projects, case studies, seminars, exercises and site visits. The course is held by Ex Cathedra lectures, project analysis, with interactive close supervision of design works during exercises. Furthermore, contemporary lectures, and exercises during class use different audio-visual techniques, software, and tools. After completing the course, students have understood and mastered the basic design principles in the field of product design:

- Students have developed design skills and techniques;

- Students have developed the skills necessary for technical qualities, anthropometry, ergonomics and product aesthetics;

- Students have developed skills and techniques to describe, analyz and articulate the interdisciplinary design process;

- Students have developed the ability to document and present the creative design process, in particular with: methods used, activities undertaken and research conducted.

Nowadays, we have multifunctional and complementary studies as a result of the globalization trends, strengthened with the high technology development. Therefore, those phenomena can realistically do impact on the global labor market, hence, the whole global academia network are holistically interdependent within a wide product industry subsystem, thus forming the future global labor market. Actually, the global product industry development is faced with many challenges especially being pressured on price and quality, thus, these aspects are more strengthened with a heavy global concurrence. On the other hand, "It took me a long time to understand the relationship between ideas and between objective facts. But after I clearly understood this relationship, I didn't fool 
around with other wild ideas. That is one of the main reasons why I just make my scheme as simple as possible." (Ludwig Mies van der Rohe).

Fig. no. 1. Quality definition model: Actions to exploit quality on teaching for product design processes. (Bajçinovci, 2019)

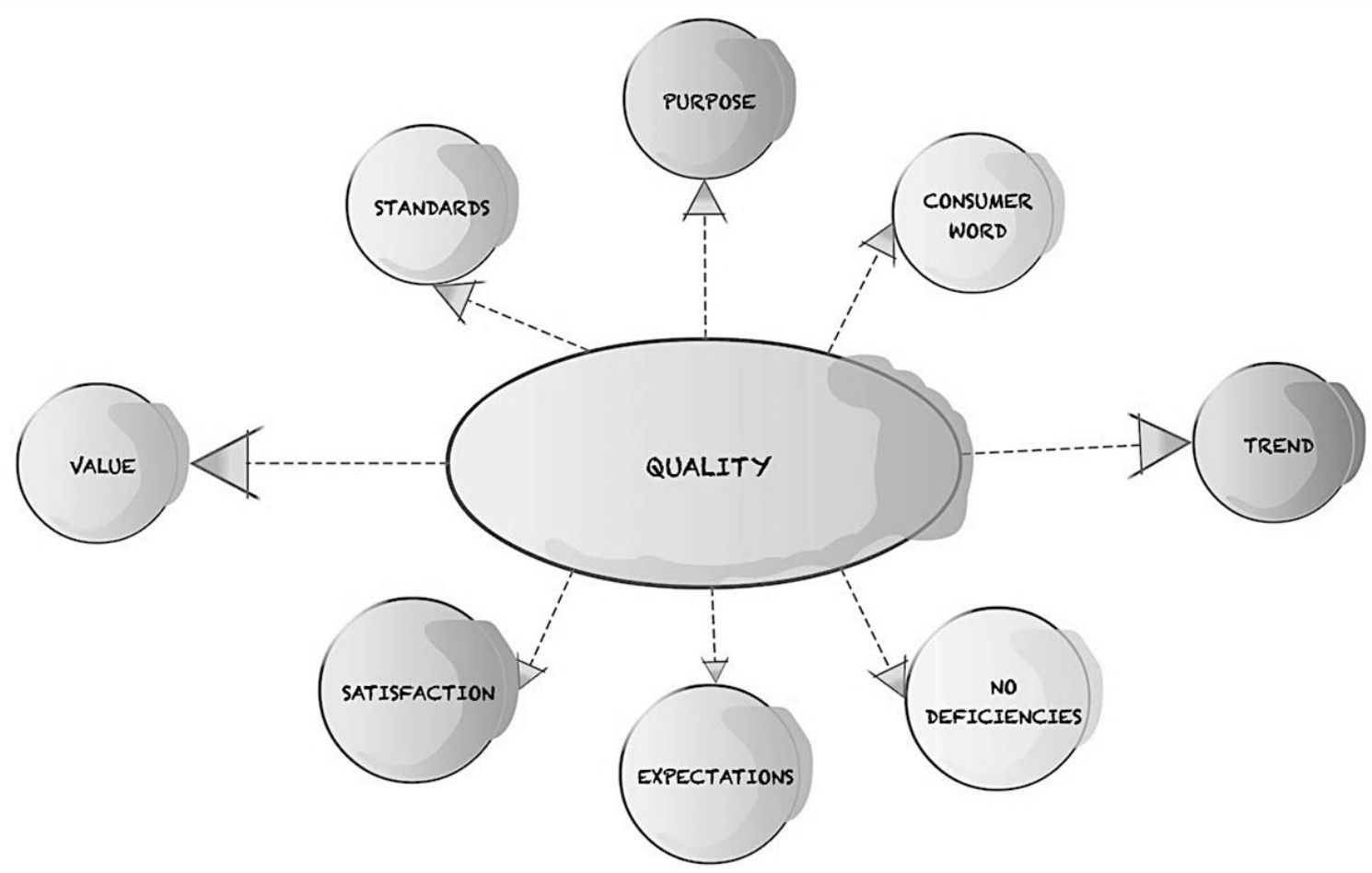

Fig. no. 2. Product Quality definition model: Actions to exploit product quality on teaching for product design processes. (Bajçinovci, 2019)

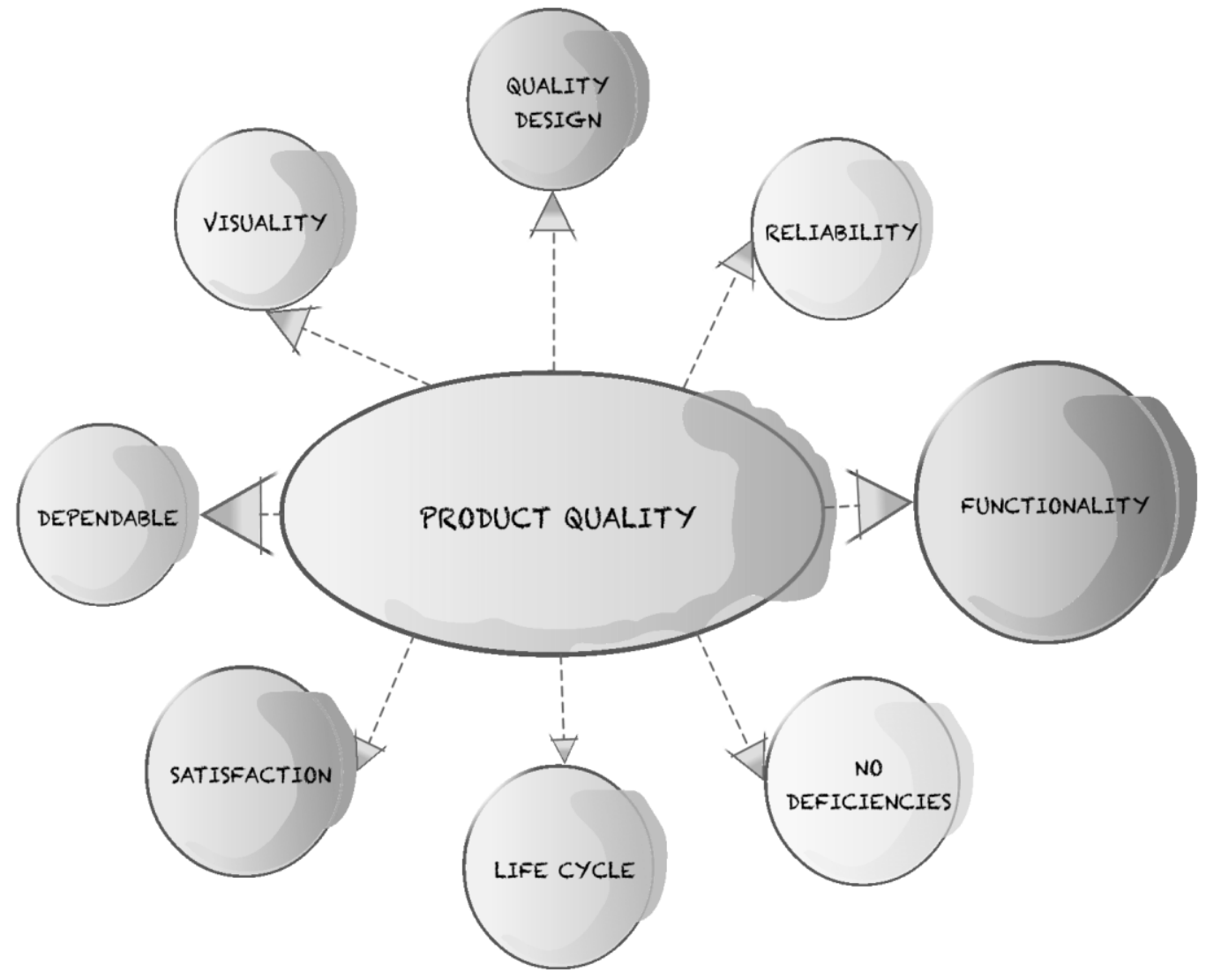


Furthermore, Hawking in his work: A brief history of time, states: "In real time, the universe has a beginning and an end at singularities that form a boundary to space-time and at which the laws of science break down. But in imaginary time, there are no singularities or boundaries. So maybe what we call imaginary time is really more basic, and what we call real is just an idea that we invent to help us describe what we think the universe is like"240

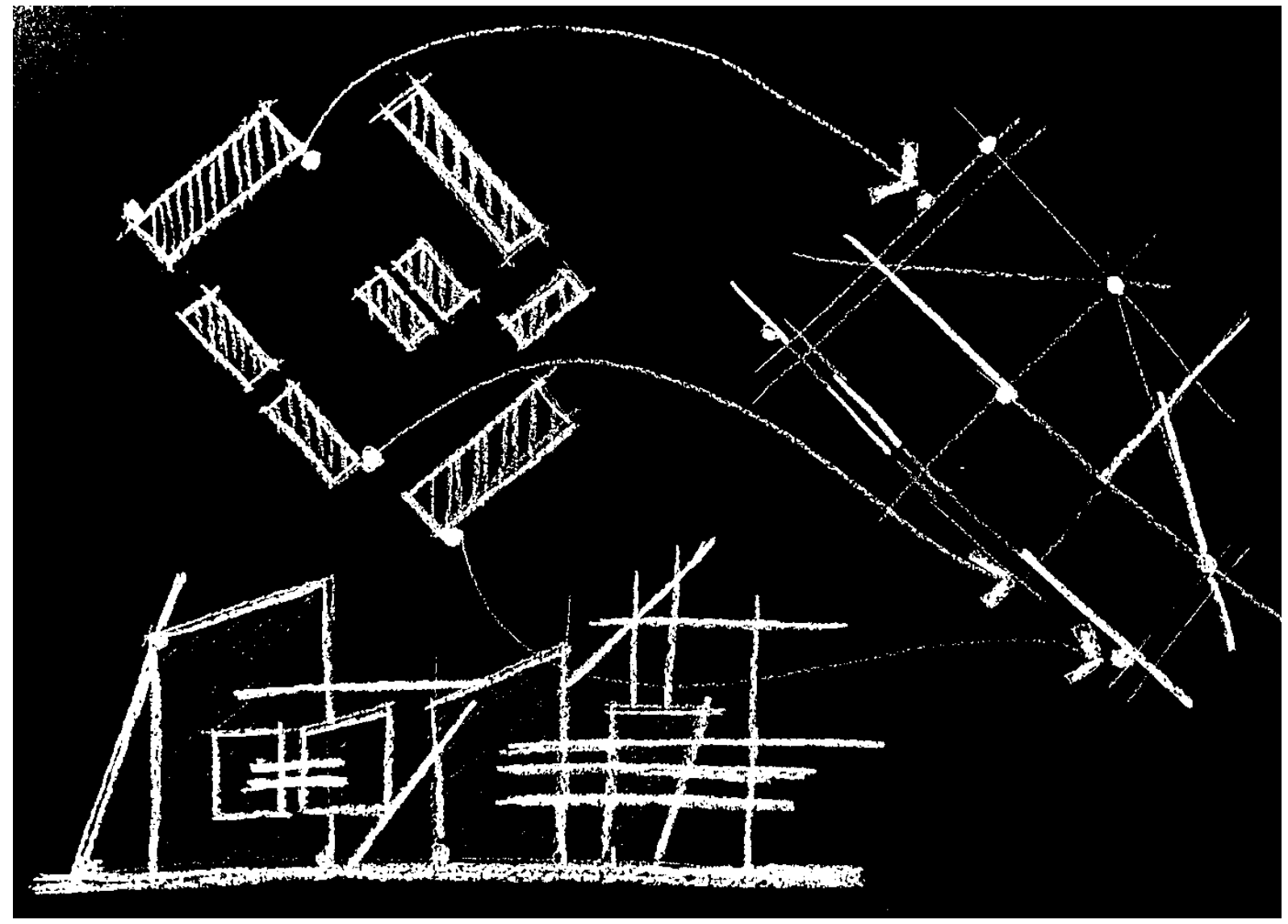

Fig. no. 3. Conceptual drawings, a holistic approach to the sum of all parts. Contemporary art reflection of Calvino's Invisible Cities prose poems. (Bajçinovci, Thaçi, 2017)

"The future art public won't be a simple passive receiver, easy to manipulate, but, through a harmonious development of the soul functions and of the intellectual abilities, it will be able to develop its own creative, response and selection capacities for the messages coming from the social environment, messages that can distort the perception of reality and of internal representations. ${ }^{241}$ Hence, formally fulfilling legal academic standards, within adapted and accredited academic frameworks, cannot be expected to solve comprehensive and future challenges, associated with the development of technology, labor market, life style, and global world trend.

\footnotetext{
${ }^{240}$ Hawking, S. A Brief History of Time. Bantam Books, Paperback, 1996.

${ }^{241}$ Paşca, Eugenia Maria. (2016). Variables and Constants in the curriculum for the music specializations of the Romanian University Education. Review of Artistic Education no. 11-12 2016, pp. 253-262.
} 


\section{Conclusions}

The present state of academia requires specific contemporary methods, especially when the situation is directly linked to the quality of teaching and future challenges of the labor market. "Education, of course, is always based on what was. Education shows you what has been and leaves you to make the deduction as to what may be. Education as we pursue it cannot prophesy, and does not". ${ }^{242}$ Findings in this paper indicate that through quality aspects of product design in artistic education teaching methods as contemporary learning strategies strengthened with informal meeting places for education, can concurrently present a teaching strategy, by which can bring more clarity to the academia and product design industry. Hence, new teaching strategies must involve a new closeness, a brand new and more refining holistic system, as a response to less functional academic curriculums. The current classic teaching methods, formally fulfilling academic, and legal standards, requires a serious approach of academia for the contemporary teaching methods.

\section{References}

1. Bajçinovci, B., Thaçi, K., Bajçinovci, B. (2017). Architectural Reflection on Italo Calvino's Invisible Cities. Journal of Science, Humanities and Arts. Freiburg. Germany, DOI: 10.17160/josha.4.1.261.

2. Bajçinovci, B., Jerliu, F. (2017). The Concept of "Modelarium" and its Impact on Creativity and Artistic Education. Review of Artistic Education no.14 2017. De Gruyter. DOI: 10.1515/rae-2017-0030.

3. Bajcinovci, B., Aliu, V. (2018). Visual Organization of Industrial Functional Compositions, JOSHA. Freiburg. Germany. DOI: 10.17160/josha.5.5.437.

4. Bajçinovci, B., Bajçinovci, U., Bajçinovci, B. (2019). Interactive Academic Education and its Impact on Urban Development - History and Contemporaneousness. Review of Artistic Education.Vol 18, Is.1.Sciendo. Lasi, Romania. DOI: 10.2478/RAE-2019-0029.

5. Bajçinovci, B. (2019). Syllabus of Product Design, The Faculty of Arts. The University of Prishtina.

6. EuroStudent. http://database.eurostudent.eu/113, (Accessed: October 2019).

7. Hawking, S. A Brief History of Time. Bantam Books, Paperback, 1996.

8. Paşca, Eugenia Maria. (2016). Variables and Constants in the curriculum for the music specializations of the Romanian University Education. Review of Artistic Education no. 11-12 2016, pp. 253-262. DOI: 10.1515/rae-2016-0030 9. University of Prishtina, The Rector's speech. UP -Yearbook 2019. 10.Wright, Lloyd, F. (1955). https://christen.community.uaf.edu /2013/05/26/frank-lloyd-write-on-education/, (Accessed: October 2019).

\footnotetext{
${ }^{242}$ Paşca, Eugenia Maria. (2016). Variables and Constants in the curriculum for the music specializations of the Romanian University Education. Review of Artistic Education no. 11-12 2016, pp. 253-262.
} 